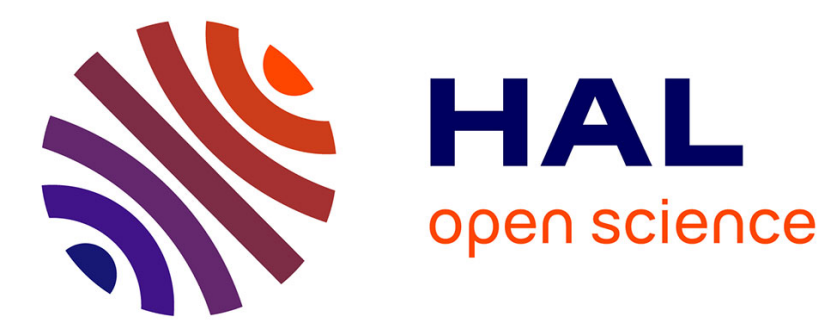

\title{
Guaranteed minimum income and unemployment duration in France
}

Antoine Terracol

\section{To cite this version:}

Antoine Terracol. Guaranteed minimum income and unemployment duration in France. Labour Economics, 2009, 16, pp.171-182. 10.1016/j.labeco.2008.08.007 · hal-00607219

\section{HAL Id: hal-00607219 https://hal.science/hal-00607219}

Submitted on 8 Jul 2011

HAL is a multi-disciplinary open access archive for the deposit and dissemination of scientific research documents, whether they are published or not. The documents may come from teaching and research institutions in France or abroad, or from public or private research centers.
L'archive ouverte pluridisciplinaire HAL, est destinée au dépôt et à la diffusion de documents scientifiques de niveau recherche, publiés ou non, émanant des établissements d'enseignement et de recherche français ou étrangers, des laboratoires publics ou privés. 


\title{
Guaranteed minimum income and unemployment duration in France
}

\author{
Antoine Terracol ${ }^{1}$ \\ EQUIPPE (Université Lille 3), and Université Paris 1 Panthéon-Sorbonne, CNRS. CES, \\ 106-112 boulevard de l'Hôpital, 75642 Paris cedex 13, France.
}

\begin{abstract}
In this article, we use data from the European Community Household Panel to evaluate the impact of a French guaranteed income program, the RMI, on the the hazard out of unemployment. Self-selection into the program is corrected using a multivariate duration model developed by Abbring and van den Berg (2003). We find that RMI receipt has a strong negative impact during the first months of program participation, but that this disincentive effect quickly falls to insignificant levels after six months. Household structure also appears to be an important determinant of the importance of the adverse effect of program participation.
\end{abstract}

Key words: unemployment duration, welfare programs, duration models, endogeneity JEL Codes: C41; I38; J64

\section{Introduction}

Income maintenance programs were primarily designed to provide poor individuals or families with the means to uphold a minimal standard of living. While equity considerations and distributional issues were the main reasons these programs were created, rising caseload and the increasing cost for public finances, especially in times of high unemployment, have quickly raised concerns about their potentially adverse effects on recipients' labour supply behaviour. The debate over such side effects has focused on issues such as poverty and inactivity traps associated with

Email address: terracol@univ-parisl.fr(Antoine Terracol).

1 I wish to thank two anonymous referees, as well as Denis Fougère, David Margolis, Jean-Marc Robin, Véronique Simonnet and participants in various seminars for helpful comments. The usual disclaimer applies. 
high effective marginal tax rates on labour income, the loss of job skills or, more generally, of human capital that was likely to deter re-entry into employment.

Empirical studies of the impact of means-tested benefits on the labour supply behaviour of its recipients have mainly focused on the North American labour market. A large non-experimental literature has concentrated on the effects of USA's AFDC program and its post-1996 version, the TANF. Both programs have been extensively studied. A survey of the empirical evidence on their effects on the labour market behavior of its recipients can be found in Moffit (2001), and the impact of the 1990's welfare reform is discussed in Blank (2002) and Grogger and Karoly (2005). The findings confirm that such programs reduce hours of work, with an estimated effect ranging from 10 to $50 \%$. Effects of common features of these programs, such as earning disregards or work requirement have also been evaluated. While experimental evidence (Michalopoulos et al., 2005) has shown that strong financial incentives increased labour market participation, especially when coupled with work requirement; non-experimental studies have concluded that lowering the benefit reduction rate (the rate at which benefits are withdrawn as labour income rises), although increasing the labour supply of welfare recipients, had no sizeable impact on overall labour force participation because some non-recipients cut their labour supply to gain eligibility.

Lessons, however, can also be learnt from European income maintenance programs, as the level and extent of these programs are typically more important and widespread in the 'old world' than in North American countries. France, in particular, has implemented since December 1988 a nationwide means-tested benefit, the Revenu Minimum d'Insertion (RMI hereafter) providing households below a given income threshold with a monthly guaranteed minimum income. Over the years, as more and more unemployed became eligible and took-up the benefit, RMI has evolved into what has been described as a "[new] component of the unemployment compensation system" in official reports (Commissariat Général du Plan, 2000), raising concerns about its possible effects on labour supply. Indeed, unlike AFDC/TANF, eligibility to the RMI is not restricted to certain types of families, neither is receipt limited to a given amount of time, or conditioned on work requirements. Also, unlike UK's Income Support, eligibility is not limited to those unable to work. For the sizeable fraction of its recipients that are unemployed, the RMI can be seen as a substitute for traditional unemployment insurance. Because RMI involves no degressivity and no job search requirements, its effects on labor supply behavior are likely to be stronger than traditional UI benefits that typically impose stronger requirements designed to increase job search incentives. Moreover, rising caseload (over one million households since 1996, compared with roughly 2.5 millions receiving traditional UI) increases the likelihood that the aggregate impact of RMI on unemployment is sizeable We therefore examine in this article how RMI receipt affects the transitions into employment for its unemployed recipients. In contrats with the majority of studies of welfare programs that have used a static framework, focusing on labour force participation rates, average hours worked or 
earnings, we adopt a dynamic framework by focusing on individual transition rates from unemployment to employment.

In the absence of controlled experiments specifically designed to evaluate income maintenance programs in France, the identification of the effect of RMI recipiency relies on the fact that a fraction of eligible individuals will not, for various reasons, actually take-up their rights to the benefit, thus providing us with a comparison group to evaluate the causal effect of RMI receipt. Indeed, the literature on welfare participation has shown that eligible individuals usually exhibit an imperfect takeup behaviour, with a take-up rate ranging between 40 and $80 \%$ according to the type of benefit (Hernanz et al., 2004; Currie, 2004); and which crucially depends on their prospects on the labour market. However, because potentially unobservable characteristics driving the take-up behaviour might be correlated with labour supply, participation in the RMI program cannot be considered exogenous, even in a sample of eligible individuals, and after controlling for observable characteristics. Our empirical method deals with this potential endogeneity of welfare participation through the estimation of a multivariate duration model that allows identification of treatment effects (Abbring and van den Berg, 2003). Our results show that participation in the RMI program reduces the hazard rate to employment by about $38 \%$; adding between 4 and 9 months to the unemployment spells of its recipients. However, this impact varies significantly among different household types, and decreases sharply with the length of the welfare spell.

The remainder of the paper is organized as follows: We describe the RMI program and its link to the unemployment compensation system in Section 2 and present our data in Section 3. We discuss the estimation procedure in Section 4 and comment on the results in Section 5. Finally, Section 6 concludes.

\section{The RMI program}

The French welfare system has largely been built around various programs aimed at specific categories of individuals (the disabled, the elderly, the single parents, etc.). The sharp rise in unemployment during the late 70's and 80's had made clear that the French social security system lacked an universal benefit that would act as an income maintenance program for those not targeted by the various benefits already in place. To fill the gap in the safety net, the Revenu Minimum d'Insertion was created in December 1988, and provides every household below a certain income threshold with a guaranteed income. In January 2000, the income threshold was $€ 389$ for a single person, $€ 583$ for a 2 persons household, $€ 700$ for a 3 persons household, and $€ 155$ for each additional member ${ }^{2}$. Eligibility to the benefit is

$\overline{2}$ The net monthly minimum wage for a full-time job was $€ 866$ in 2000 . The guaranteed income represents about $60 \%$ of the official poverty line for the corresponding household 
triggered if the household's average income over the previous three months falls below the threshold. The actual benefit paid is defined as the difference between the household's income (including other income transfers) and the threshold. It is reassessed every three months, and is paid for as long as the households remains eligible.

Since its introduction, the RMI caseload has risen threefold, from 400,000 in 1989 to over 1.2 millions in 2003. Its total cost has followed a similar path, and has reached $€ 4.8$ billions, about two third of the budget allocated to welfare programs addressing social exclusion in France. Figure 1 shows the evolution of caseload and cost (in constant $2000 €$ ) from 1989 on.

Figure 1. RMI caseload and cost

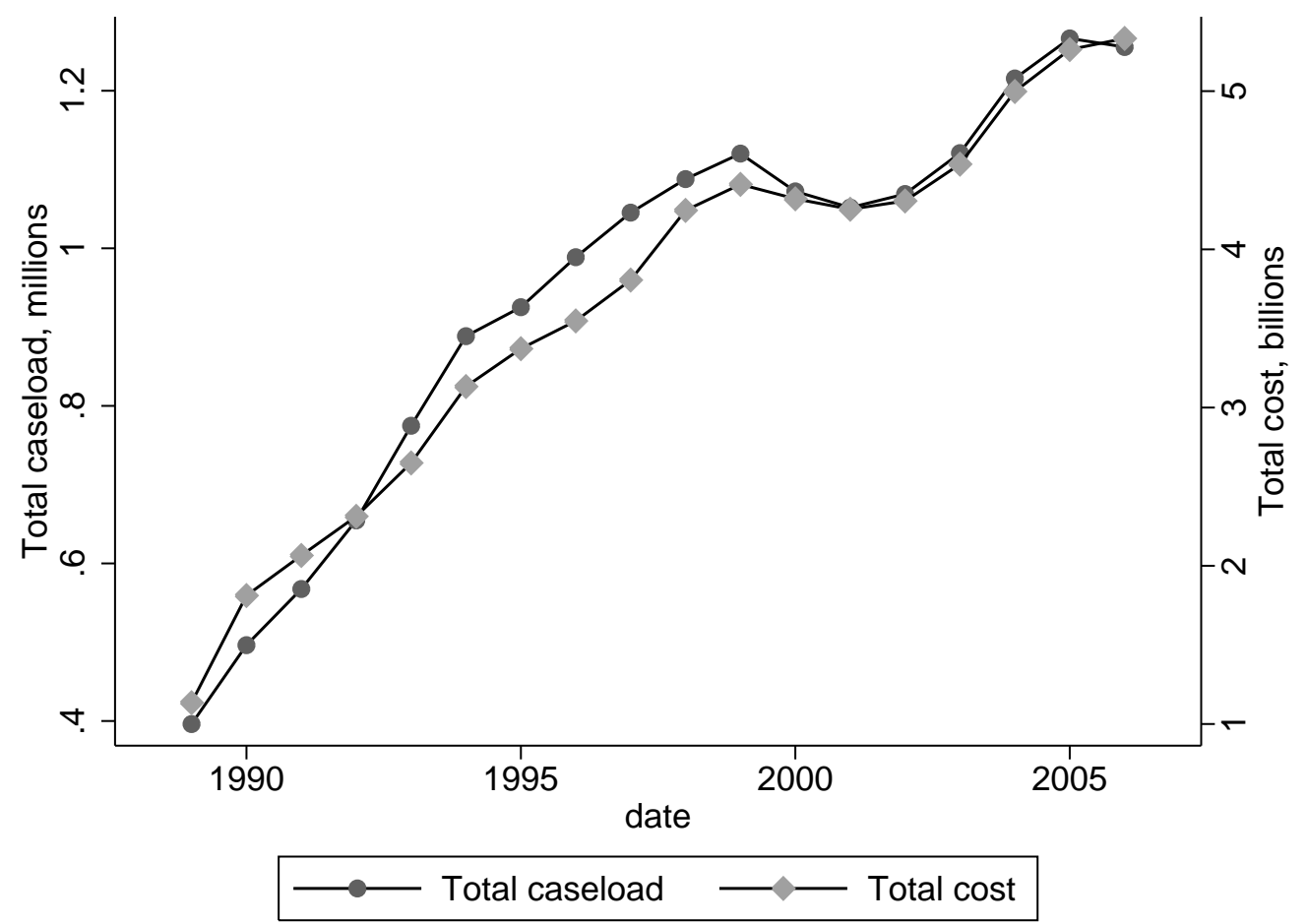

The evolution of RMI caseload appears to be linked to variations in the unemployment rate. Figure 2 plots the unemployment rate and the proportion of RMI recipients in the population aged 25 and more ${ }^{3}$; and shows that, after an initial rise in caseload, the two proportions follow similar paths. A more detailed study by Jacobzone (1996) has shown that the inflow of RMI recipients was impacted by the flow into uncompensated unemployment with a three to six months delay. Unlike United Kingdom's Income Support, which is specifically targeted to those who are not actively seeking work, the RMI has no specific eligibility rules concerning the

type.

3 One must be at least 25 to qualify for RMI receipt. 
claimants' labour market status. Thus, individuals who have exhausted their rights to UI benefits, or who have not worked long enough to trigger UI entitlement will become eligible to RMI benefits as soon as their income fall below the threshold. In this respect, the RMI program bears some resemblance with Germany's Arbeitslosenhilfe (now Arbeitslosengeld II), which also covers unemployed individuals without UI entitlement. Moreover, individuals who cannot work are often entitled to other, more specifically targeted, benefits (Allocation Adulte Handicapé for the disabled, Allocation Parent Isolé for lone parents, Social security benefits for the long-term sick, etc.). Hence, a substantial fraction of RMI recipients are not out of the labour force nor unable to work, and are considered as unemployed ${ }^{4}$, and RMI has become a de facto form of unemployment benefit. In January 2004, new rules aimed at providing more work incentives to RMI recipients, and hiring incentives to potential employers have been introduced. Renamed "RMA-CI" (Revenu Minimum d'Activité-Contrat d'Insertion), the modified version of RMI, a recipient that finds a new job can receive its full wage, while the employer only pays the difference between the newly hired's salary and his RMI allowance. A study of registered unemployed (Observatoire de l'ANPE, 2002), comparing RMI recipients and non recipients, has found that the former are disproportionately male and low-educated: $75 \%$ have not completed high school, versus $60 \%$ of non recipients. However, they also find that RMI recipients registered with the employment agency (ANPE) have slightly better characteristics than unregistered RMI recipients.

Although the relation between RMI and unemployment have been widely acknowledged, RMI rules retain unappealing features with respect to work incentives. The RMI being a differential allowance, its beneficiaries are subjected to a $100 \%$ implicit tax rate on any additional income below the threshold, severely limiting the financial gain from switching from welfare to labor income (Join-Lambert, 1998; Pisani-Ferry, 2000; Laroque and Salanié, 1999). In some cases, since the RMI is linked to other welfare benefits, switching from RMI to part-time employment can actually lower the household's disposable income. Because of these adverse financial incentives, we expect the RMI program to have a strong negative impact on the transition rate from unemployment to employment. However, other features of the RMI program have been designed to offset the adverse effects of the benefit on job seekers. First, the welfare earnings top-up program (intéressement) allows a RMI recipient that starts a new job to continue to receive the RMI benefit at full rate for 3 months (lowering the implicit marginal tax rate to $0 \%$ ), and at half rate for another 9 months (generating a 50\% implicit marginal tax rate during that period). Stronger financial incentives, as well as incentives for employers to hire RMI recipients have been added in 2005, but our data only covers years 1997 to 2000 . Second, the RMI program includes a compulsory 'insertion contract' whereby recipients, with the help of their caseworker, define priority actions they undertake to do in order to improve their social inclusion. These actions might include health, housing, job search etc. About $90 \%$ of 'insertion contracts' state that job search is

$\overline{4}$ Over $60 \%$ of RMI spells end with a transition to employment, Afsa and Guillemot (1999) 
the recipient's main priority, but RMI recipients are not obliged to follow the caseworker's suggestions about the content of the contract. It is estimated that only half of RMI recipients have actually signed an insertion contract (Zoyem, 2001), mainly because caseworkers have not asked the other half to do so. Moreover, although sanctions can theoretically be pronounced for non-compliance with the contract, very few are actually pronounced. This weak conditionality of benefit receipt to compliance with insertion contracts is reinforced by the fact that the administration in charge of benefit payment differs from the one in charge of the insertion contracts. So, although such 'insertion contracts' have been found to reduce welfare dependency in the Spanish case (Ayala and Rodríguez, 2006), doubt can be cast on the actual efficiency of such non pecuniary incentives in the French case. Although Zoyem (2001) has found that such contracts had a positive effect on transitions from welfare to work, his study does not correct for the endogeneity of contracts, thereby over-estimating their effects. Roughly one half of insertion contracts ( $22 \%$ of RMI beneficiaries) have signed a contract involving some sort of training. These training sessions could in principle involve a lock-in effect and lead to longer unemployment spells for those taking part. However, only a fraction of recipients are engaged into such training, so this potential lock-in effect should not affect our results in a significant way. Unfortunately, our data does not include information on insertion contracts ${ }^{5}$, and this study will only focus on the overall effect of RMI receipt.

In a recent paper, Gauthier (2008) conducts a thorough study of the RMI program in a partial equilibrium search framework. His main conclusions are that individuals on RMI should have a lower exit rate into employment than equivalent individuals not on RMI. Moreover, when a temporary disregard is added to the program ${ }^{6}$, Gauthier (2008) finds that it should have an adverse effect on re-employment rates if the disregard is high enough, and no effect if it is too low.

Despite the strong link between RMI and unemployment, and the unambiguous theoretical predictions, empirical studies of the causal effect of welfare recipiency on labour supply behaviour in France have been scarce; and their conclusions are still at debate. Maurin and Torelli (1992) conclude that RMI receipt does not have a statistically significant impact on the employment probability on the following year, and that it has a negative and significant impact on transitions out of the labour market. More recently, Granier and Joutard (2002) conclude that RMI receipt has no effet on the exit rate from unemployment, except for single parents ${ }^{7}$.

\footnotetext{
5 To our knowledge, no dataset including both RMI recipients and non-recipients provide information about insertion contracts.

6 As it is the case with the actual RMI rules, see above

7 This finding could be explained by the fact that, in their dataset (Enquête-Emploi), Granier and Joutard only observe RMI receipt at interview dates. This left-censoring of RMI spells could lead to biases in the estimates if RMI effect is time-varying. See also footnote 12
} 
Figure 2. Unemployment rate and proportion of RMI recipients

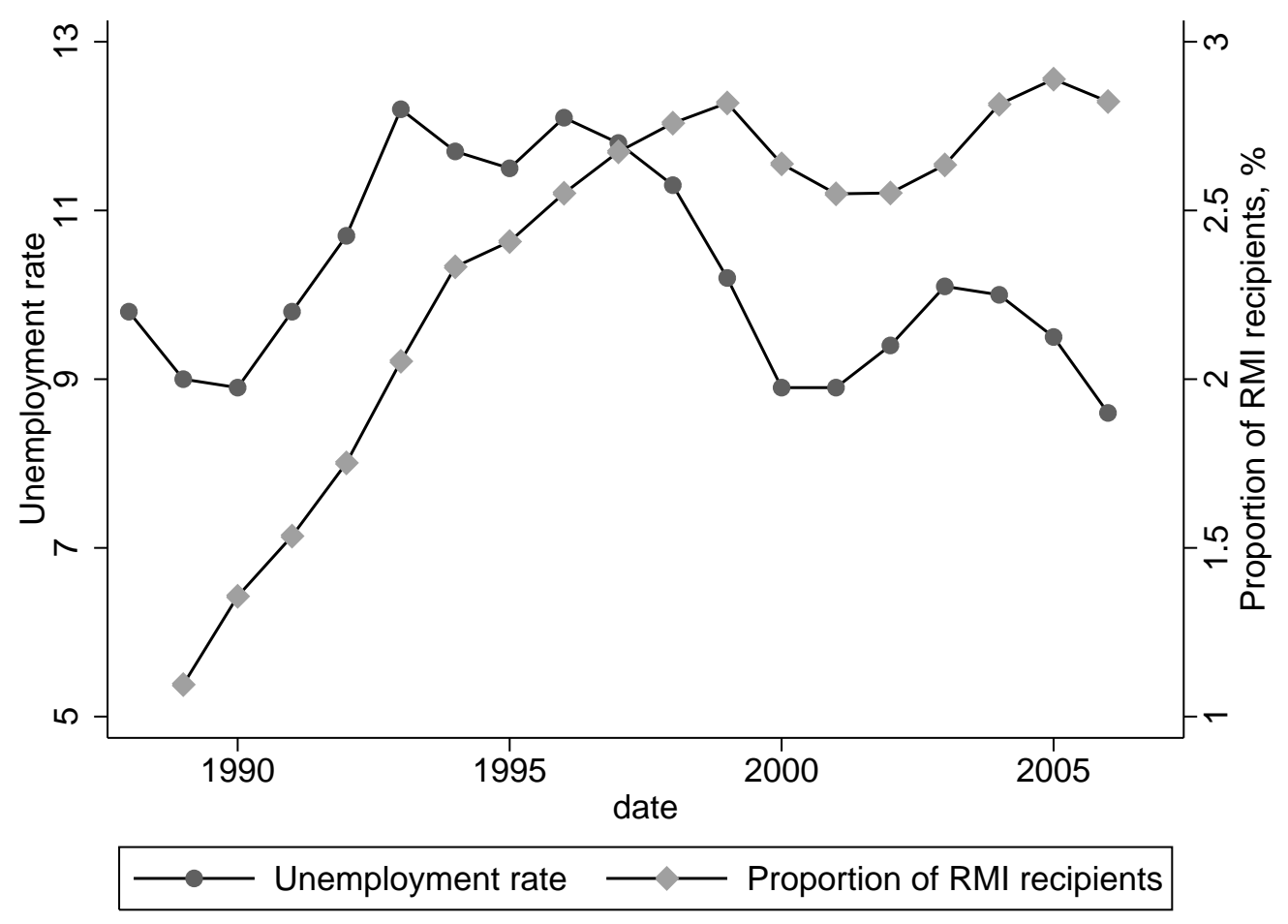

Using a different methodology, centered on the financial gains from exiting from unemployment, Gurgand and Margolis (2008) conclude that most RMI recipients would experience an increase - very small on average - in their disposable income by switching to paid employment; and that the RMI top-up program has very little impact. Although many jobs found by RMI recipients are low paid, short term contracts, the conclusions of their study tend to minimize the potential inactivity trap effect induced by the RMI program ${ }^{8}$. Another study by Margolis and Starzec (2002), which uses a detailed simulation of French taxes and transfers, also concludes that inactivity traps effects are not significant. On the contrary, Laroque and Salanié $(2000,2002)$ and Piketty (1998) insist on the importance of financial incentives on the exit rate from unemployment, and on the disincentive effects of the RMI program, especially on women.

Most - if not all - studies of the impact of welfare programs have overlooked the non take-up phenomenon that is now widely documented in the literature (Moffitt, 1983; Duclos, 1995, 1997; Blank and Ruggles, 1996; Blundell et al., 1988; Bollinger and David, 2001; Riphahn, 2001; Hancock et al., 2004). Take-up of the RMI benefit has been studied by Terracol (2002), who finds that up to $35 \%$ of el-

\footnotetext{
8 Although individuals would earn more if they were re-entering employment, that does not mean they would choose to do so, because of associated costs (child care, transportation) or a high disutility of labour.
} 
igible individuals chose not to sign-up for the benefit. The fear of social stigma is thought to be one on the main causes for non take-up of welfare benefits by eligible agents, along with participation costs and imperfect information on the availability of the benefit (Besley and Coate, 1992; Dahan and Nisan, 2006). Because of this self-selection phenomenon, the issue of non take-up must be tackled when trying to assess the impact of welfare programs on its recipients. Non participation in a welfare program by eligible individuals is driven by characteristics not always observables by the analyst, and those characteristics may be correlated with the unobservables diving the process of labour supply. Hence, program participation is probably endogenous in a model of unemployment duration, even when one focuses on a sample of otherwise similar poor and low-educated eligible individuals, and must be modeled as such. Our estimation strategy is thus based on the model developed by Abbring and van den Berg (2003), which allows the identification of a dynamic treatment effect in a duration model framework, where the treatment is not independent of the outcome of interest.

\section{Data}

We use the first seven French waves of the European Community Household Panel (ECHP) data set, between 1994 and 2000. This data set contains detailed information on individuals' household structure, labour market status and income on a monthly basis. RMI receipt is also recorded monthly ${ }^{9}$. Although the ECHP does not contain an RMI eligibility variable, we are able to compute it by adding all relevant income types ${ }^{10}$ received each month by all members of the household ${ }^{11}$, and, following official eligibility rules, calculate whether the average household income over the previous three months falls below the threshold corresponding to the individual's household structure. If an household is classified as eligible, all its adult members are considered eligible. The ECHP was not targeted towards low-income households, and might under represent RMI recipients, as this population is usually harder to reach and follow over time. However, it is the best suited dataset for our study since its detailed calendars allow us to follow households' income and individuals' transitions in the labor market on a monthly basis. Moreover, individuals

9 The French version of the ECHP questionnaire has a specific item for RMI receipt, separate from other social exclusion benefits.

${ }^{10}$ The ECHP income calendar lists 34 types of income. The RMI eligibility rules excludes certain types of income from the threshold calculation, such as bursaries or negative income tax. Note that UI benefits are included in the calculation of the household's income and that both UI and RMI benefits can be received at the same time if the former is low enough for the household not to cross the threshold.

${ }^{11}$ Changes in the household structure can be computed using the "household composition" form indicating the dates of arrival of new household members, as well as the date of departures of former members. 
who moved between two waves were interviewed in their new dwellings, rather than discarded from following waves ${ }^{12}$.

Because eligibility to the RMI program depends on an income threshold which varies according to the household structure, and because the UI replacement rate depends on a variety of factors, only a fraction on unemployed individuals will experience one or more eligibility spells while unemployed. Those latter individuals are typically young, without enough contributions to benefit from unemployment insurance, or are long term unemployed who have exhausted their rights to UI benefits. To construct our sample, we have selected all the unemployed individuals that have participated during at least a month in the RMI program (or if one adult member of the household reports RMI receipt), as well as all the unemployed that have experienced at least a month of eligibility ${ }^{13}$ (even if they did not take up their rights) during their unemployment spell. Hence, only the unemployment spells long enough to trigger eligibility to the RMI program via a drop in households' income are included in the sample. This over sampling of long spells will be corrected for in our statistical model. Moreover, because single mothers with children under 3 years of age can receive a specific benefit higher than the RMI threshold (and will thus never be eligible), they are discarded from our sample.

After discarding left censored unemployment spells, and censored ongoing spells at 36 months, our final sample consists of 1078 unemployment spells, 584 of which end with a transition into employment, and 494 are right censored ${ }^{14}$. This relatively small sample size should be kept in mind when analyzing results, as coefficients will be less precisely estimated than in a larger sample.

Table 1 gives summary statistics for the main variables ${ }^{15}$ for the whole sample,

\footnotetext{
$\overline{12}$ Another popular choice for studies of RMI recipients is the French Labor Force Survey (Enquête-Emploi. However, it only provides information on RMI recipiency at the date of the interview, and seniority in the program is not known. This left-censoring of RMI spells seems ill suited for a study where the timing of events is an essential part of the empirical analysis. Moreover, the ECHP has a better coverage of RMI recipients than the Enquête Emploi does (Terracol, 2003))

${ }^{13}$ Because of the common under reporting of income in questionnaire surveys, it is possible that some of the households whom we classify as eligible are in fact not eligible.

${ }^{14}$ Among the 494 censored spells, 138 (27.5\%) are censored due to panel attrition. We assume throughout the paper that attrition is independent of the duration processes, conditionally on the included covariates and unobserved heterogeneity. This is a common hypothesis in duration analysis; and van den Berg et al. (1994) found that, in their setting, explicitly modeling the attrition process had no impact on estimated coefficients.

${ }^{15}$ Apart from the variables Spell duration, Transition into employment, Months before eligibility, Months before RMI receipt and Unemployment insurance, figures in the table are the values of these variables at the beginning of the unemployment spell. The variable $U n$ employment insurance takes the value 1 if the individual has benefited from unemployment insurance for at least a month during their unemployment spell, and 0 otherwise.
} 
and according to RMI receipt. For each variable, we indicate the result of a t-test with unequal variances for the null hypothesis that the two sub samples have equal means. Those summary statistics indicate that, despite some minor differences, both populations are quite similar. The only statistically significant differences between the two sub samples concern household structure and unemployment-related variables. The sub sample of RMI recipients contains proportionally more single parents and less one-person households than the sub sample of eligible non beneficiaries. Its members are typically younger, have longer unemployment spells and benefit less often from unemployment insurance. More than half of unemployment spells, for RMI recipients and non-recipients alike, end with a transition into employment, which is consistent with the findings of Afsa and Guillemot (1999). Eligibility to the RMI benefit occurs relatively early in individuals' unemployment spells, and those taking-up the benefit do it relatively early (the 1.5 month difference between eligibility and actual receipt is likely to be largely due to administrative delays). The observed unemployment spells is on average 6 months (60\%) longer for RMI recipients than for individuals who do not take up their rights, which indicates a potential strong adverse effect of RMI receipt of the transitions out of unemployment. Non-parametric estimates ${ }^{16}$ of the survival functions depicted in Figure 3 suggest that program participation have a strong impact on re employment probabilities. Non parametric tests reject the null hypothesis of the equality of survival functions at the $1 \%$ level. ${ }^{17}$

Our sample statistics show some dissimilarities with administrative data that are worth commenting. First, our sample contains more couples (with and without children) than can be found in administrative data. This coud be explained by the fact that some unmarried couples might tell their caseworkers that they are single in order to avoid their partner's income to be included in the calculation of their entitlement level. Another reason for this difference might be that individuals living in homeless shelters are not sampled in the ECHP, and they constitute a sizeable fraction of the single-persons RMI recipients. Interestingly, our sample statistics for household composition are similar to those obtained from other labour-force surveys, such as the one used in Granier and Joutard (2002), or the more specific survey of RMI recipients in Lhommeau (2001), who analyses the discrepancies between administrative and survey data on RMI recipients. Second, individuals in our sample seem to be more educated than what can be observed in an administrative dataset. Again, it could be explained by the exclusion of the homeless from the sampling scheme of the ECHP and because, more generally, the less educated individuals might have more disrupted histories and be more difficult to follow from dwelling to dwelling. These discrepancies, while difficult to avoid when using survey data, might lead to inaccuracies in the estimates of RMI receipt.

\footnotetext{
16 These estimates take into account the stock-sampling bias that arises from our sampling scheme.

${ }^{17}$ Log-rank test: $\chi^{2}(1)=11.57$, p-value $=0.0007$; Wilcoxon test: $\chi^{2}(13.71)$, pvalue $=0.0002$
} 
Figure 3. Survival estimates

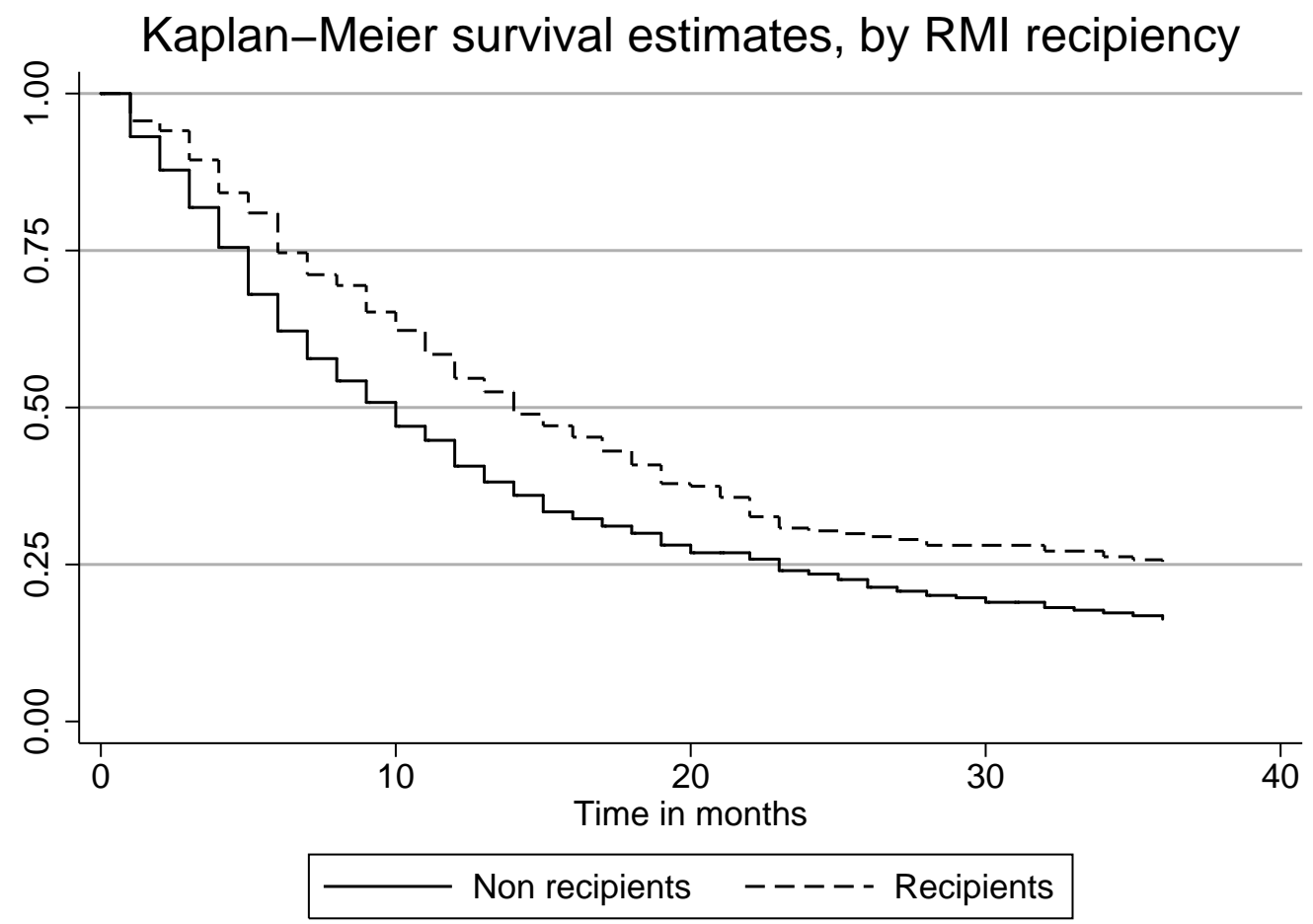

\section{Statistical model}

In our data, for each unemployment spell, we observe the time elapsed until the individual becomes eligible to the RMI benefit, as well as the (possibly censored) time elapsed until she actually receives it. We also observe the length of her (possibly censored) unemployment spell. Our empirical analysis will focus on how RMI receipt affects the time to re-employment. Because welfare participation might be correlated to unemployment duration via their unobserved determinants, even among a sample of eligible individuals, one cannot consider program participation as exogenous, and must analyse the two processes jointly. Indeed, a growing literature on take-up behaviour have shown that agents choose whether or not to participate into welfare programs according to observed and unobserved characteristics. See for example Moffitt (1983), Duclos (1995, 1997), Blank and Ruggles (1994), Bollinger and David (2001), Hancock et al. (2004) and others. Concerning the RMI program, Terracol (2002) has estimated an average take-up rate of $65 \%$, with some variations across household types.

We start our analysis by specifying a Mixed Proportional Hazard (MPH) duration model for the transitions from unemployment to work ${ }^{18}$. Let $t_{r}$ be the date of the

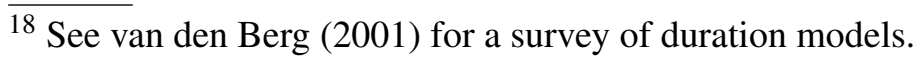


first RMI receipt, and $\mathbb{1}_{\left(t_{r}<t\right)}$ a dummy variable indicating if the individual is participating in the program at time $t^{19}$. The hazard function out of unemployment is:

$$
\lambda_{u}\left(t \mid X, t_{r}, \delta_{u}\right)=\lambda_{u 0}(t) \exp \left(X \beta+\theta \mathbb{1}_{\left(t_{r}<t\right)}+\delta_{u}\right)
$$

where $\lambda_{u 0}$ is the baseline hasard, $X$ is a vector of observable characteristics ${ }^{20}$, and $\delta_{u}$ is a random variable representing the unobserved characteristics affecting the hazard out of unemployment. $\theta$ represents the effect of RMI receipt on the hazard rate, and is the parameter of interest of our study.

The conditional density function of $t_{u} \mid X, t_{r}, \delta_{u}$ is thus:

$$
f_{u}\left(t_{u} \mid X, t_{r}, \delta_{u}\right)=\lambda_{u}\left(t_{u} \mid X, t_{r}, \delta_{u}\right) \exp \left(-\int_{0}^{t_{u}} \lambda_{u}\left(\tau \mid X, t_{r}, \delta_{u}\right) \mathrm{d} \tau\right)
$$

Participation in an income maintenance program is likely, as argued earlier, to be endogenous to unemployment duration. Using a bivariate probit model on Canadian data, Christofides et al. (1997) show that participation in a welfare program is negatively correlated with labour market participation. Moreover, the analysis of the non take-up phenomenon for the RMI program by Terracol (2002), strengthens the hypothesis of a correlation between the two processes. Indeed, if eligible individuals choose whether or not to participate in the RMI program based on unobserved characteristics, the latter will probably be correlated with the unobserved characteristics affecting the duration of unemployment spells. The existence of take-up costs including regular meeting with the caseworker and filling out forms, or social stigma (Moffitt, 1983) can lead to such an endogeneity. Indeed, individuals who expect to exit early from unemployment can choose not to incur these costs because they feel the short length of their future welfare spell will not outweigh the costs. Hence, we should expect a negative correlation between the unobservables affecting the hazards to employment and to RMI.

To correct for this potential endogeneity, we follow Abbring and van den Berg (2003) and jointly model the processes of unemployment duration and of entry into the RMI program.

We thus define the hazard rate into RMI receipt as:

\footnotetext{
${ }^{19}$ It is assumed that individuals taking-up the RMI benefits do so for the rest of their unemployment spell.

${ }^{20}$ In our application, all covariates are (potentially) time-varying. The formal exposition of the model does not explicitly consider time-varying covariates in order to keep notations simple.
} 


$$
\lambda_{r}\left(t \mid Z, \delta_{r}\right)=\lambda_{r 0}(t) \exp \left(Z \gamma+\delta_{r}\right)
$$

where $\lambda_{r 0}$ is the baseline hasard, $Z$ is a vector of observable characteristics, and $\delta_{r}$ is a random variable representing the unobserved characteristics affecting the hazard into program participation.

The conditional density of $t_{r} \mid Z, \delta_{r}$ is:

$$
f_{r}\left(t_{r} \mid Z, \delta_{r}\right)=\lambda_{r}\left(t_{r} \mid Z, \delta_{r}\right) \exp \left(-\int_{0}^{t_{r}} \lambda_{r}\left(\tau \mid Z, \delta_{r}\right) \mathrm{d} \tau\right)
$$

As explained in Section 3, our sample only contains unemployment spells with at least one month of eligibility to the RMI program. This method over samples long unemployment spells. To correct for this sampling bias, we condition the p.d.f. of unemployment duration and of time before program participation on the corresponding survival function until RMI eligibility.

This is equivalent to the traditional stock sampling correction method used when the sample is drawn from the stock of unemployed rather than from the flow. To incorporate this sampling bias correction into our model, denote $t_{e}$ the date when the individual becomes eligible to the RMI program. Define $S_{u}\left(t_{e} \mid X, \delta_{u}\right)$ and $S_{r}\left(t_{e} \mid Z, \delta_{r}\right)$ as:

$$
\begin{gathered}
S_{u}\left(t_{e} \mid X, \delta_{u}\right)=\operatorname{Pr}\left(t_{u} \geq t_{e}\right)=\exp \left(-\int_{0}^{t_{e}} \lambda_{u}\left(\tau \mid X, \delta_{u}\right) \mathrm{d} \tau\right) \\
S_{r}\left(t_{e} \mid Z, \delta_{r}\right)=\operatorname{Pr}\left(t_{r} \geq t_{e}\right)=\exp \left(-\int_{0}^{t_{e}} \lambda_{r}\left(\tau \mid Z, \delta_{r}\right) \mathrm{d} \tau\right)
\end{gathered}
$$

Note that $S_{u}\left(t_{e} \mid X, \delta_{u}\right)$ does not depend on $t_{r}$ since eligibility always occur before actual program participation.

The corrected density functions of $t_{u}$ and $t_{r}$, conditional on the these durations being greater than $t_{e}$ are:

$$
f\left(t_{u} \mid X, t_{r}, \delta_{u}, t_{u} \geq t_{e}\right)=\frac{f\left(t_{u} \mid X, t_{r}, \delta_{u}\right)}{S_{u}\left(t_{e} \mid X, \delta_{u}\right)}
$$

and

$$
f\left(t_{r} \mid Z, \delta_{r}, t_{r} \geq t_{e}\right)=\frac{f\left(t_{r} \mid Z, \delta_{r}\right)}{S_{r}\left(t_{e} \mid Z, \delta_{r}\right)}
$$

Finally, we need to model time to eligibility in a separate equation. Indeed, because individuals can only be treated if eligible, comparisons between RMI recipients and 
non recipients must control for the process of entry into eligibility ${ }^{21}$. We thus take the hazard function into eligibility to be:

$$
\lambda_{e}\left(t_{e} \mid G, \delta_{e}\right)=\lambda_{e 0}(t) \exp \left(G \eta+\delta_{e}\right)
$$

where, as before, $G$ is a vector of observable characteristics, and $\eta$ is a conformable vector of coefficients to be estimated. $\delta_{e}$ represent the unobserved characteristics affecting the duration until eligibility. The conditional density function of $t_{e} \mid G, \delta_{e}$ is:

$$
f_{e}\left(t_{e} \mid G, \delta_{e}\right)=\lambda_{e}\left(t_{e} \mid G, \delta_{e}\right) \exp \left(\int_{o}^{t_{e}} \lambda_{e}\left(\tau \mid G, \delta_{e}\right) d \tau\right)
$$

Because $\delta_{u}, \delta_{r}$ and $\delta_{e}$ are not observable to the econometrician, we must integrate this terms out of the likelihood function. Let $G\left(\delta_{u}, \delta_{r}, \delta_{e}\right)$ be the joint distribution of the unobserved heterogeneity terms . The joint density function of $t_{u}, t_{r}$ and $t_{e}$, conditional on $X, Z$, but unconditional on $\delta_{u}, \delta_{r}$ and $\delta_{e}$ is:

$$
f_{c, r, e}\left(t_{u}, t_{r}, t_{e} \mid X, Z\right)=\int_{\delta_{u}} \int_{\delta_{r}} \int_{\delta_{e}} f_{u}\left(t_{u} \mid X, t_{r}, t_{e}, \delta_{u}\right) f_{r}\left(t_{r} \mid Z, t_{e}, \delta_{r}\right) f_{e}\left(t_{e} \mid Z, \delta_{e}\right) \mathrm{d} G\left(\delta_{u}, \delta_{r}, \delta_{e}\right)
$$

See Abbring and van den Berg (2003) for a proof of the nonparametric identification of such models, and van den Berg et al. (2004) and Abbring et al. (2005) for applications on the effect of sanctions on the transition rate out of unemployment. A key assumption for the identification of $\theta$ is the 'no anticipation' assumption. It requires that entry into program participation at time $t_{r}$ does not affect the individual's behaviour before $t_{r}$. If program participation has an adverse effect on the transition rate out of unemployment, and if individuals who anticipate program participation reduce their search intensity beforehand, then our estimate of the impact RMI receipt will be under-estimated. However, although it might be possible that individuals do anticipate RMI receipt and modify their behaviour accordingly (for example by reducing their search effort beforehand), it is likely that they will only do so when they become eligible, and apply for welfare receipt at the same time. Therefore, the only delay between eligibility and participation for these individuals will be caused by administrative delays. Richardson and van den Berg (2006) argue that if anticipation occurs shortly before actual treatment is received (as it is likely in our case), then the bias on the parameter of interest will be small.

We finally need to specify the joint distribution of the heterogeneity terms. Following Heckman and Singer (1984), we assume that $\delta_{c}, \delta_{r}$ and $\delta_{e}$ have a trivariate distribution with two masspoints each. In order to keep the estimation tractable, we impose that $\delta_{e}$ be perfectly correlated ${ }^{22}$ with $\delta_{r}$. In other words, each value of $\delta_{e}$

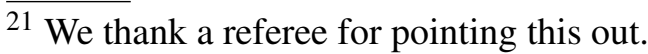

22 Positively or negatively.
} 
is associated with a given value of $\delta_{r}$.

Let $\delta_{c g}, g=(1,2), \delta_{r h}, h=(1,2)$ and $\delta_{e j}, j=(1,2)$ be the masspoints of the heterogeneity terms, the associated probabilities are:

\begin{tabular}{c|cc} 
& $\delta_{c 1}$ & $\delta_{c 2}$ \\
\hline$\delta_{r 1}, \delta_{e 1}$ & $P_{11}$ & $P_{21}$ \\
$\delta_{r 2}, \delta_{e 2}$ & $P_{12}$ & $P_{22}$
\end{tabular}

Conditional on $X, Z, t_{r}, t_{e}$ and on values of $\delta_{u}, \delta_{r}$ and $\delta_{e}$, the likelihood functions become:

$$
\begin{aligned}
l_{g h j}=\left[\frac{\lambda_{u}\left(t \mid X, t_{r}, \delta_{c g}\right) S_{u}\left(t_{u} \mid X, t_{r}, \delta_{c g}\right)}{S_{u}\left(t_{e} \mid Z, \delta_{c g}\right)}\right]^{c_{i}}\left[\frac{S_{u}\left(t_{u} \mid X, t_{r}, \delta_{c g}\right)}{S_{u}\left(t_{e} \mid X, \delta_{c g}\right)}\right]^{1-c_{i}} \\
\\
{\left[\frac{\lambda_{r}\left(t \mid Z, \delta_{r h}\right) S_{r}\left(t_{r} \mid Z, \delta_{r h}\right)}{S_{r}\left(t_{e} \mid Z, \delta_{r h}\right)}\right]^{r_{i}}\left[\frac{S_{r}\left(t_{r} \mid Z, \delta_{r h}\right)}{S_{r}\left(t_{e} \mid Z, \delta_{r h}\right)}\right]^{1-r_{i}} f\left(t_{e} \mid G, \delta_{e j}\right) }
\end{aligned}
$$

where $(g, h, j) \in\{1,2\} \times\{1,2\} \times\{1,2\}$, and $c_{i}$ (resp. $\left.r_{i}\right)$ is a dummy variable taking the value 1 if the individual exits from unemployment (resp. participates in the RMI program), and 0 otherwise ${ }^{23}$.

The baseline hazard for unemployment duration, $\lambda_{u 0}(t)$, is specified as a piecewise constant function of time by including the following time dummies among the regressors in the unemployment duration equation ${ }^{24}: \mathrm{d} t, t=1 . .5: \mathrm{d} 1=\mathbb{1}_{(t \leq 3)}$, $\mathrm{d} 2=\mathbb{1}_{(3<t \leq 6)}, \mathrm{d} 3=\mathbb{1}_{(6<t \leq 12)}, \mathrm{d} 4=\mathbb{1}_{(12<t \leq 24)}$ and $\mathrm{d} 5=\mathbb{1}_{(t>24)}$. The baseline hazard for program participation, $\lambda_{r 0(t)}$, is specified as a quadratic function of logtime, which ensures sufficient flexibility while reducing the number of parameters to be estimated. Finally, since the durations until eligibility are typically short (3.7 months on average), we use a constant baseline hazard for the corresponding process.

Using the joint distribution of the heterogeneity terms described above, we obtain the following expression for the sample likelihood, unconditional on the heterogeneity terms:

$$
L L=\sum_{N} \ln \left[\sum_{g=1}^{2} \sum_{h=1}^{2} P_{g h} l_{g h j}\right]
$$

\footnotetext{
${ }^{23}$ Since all the individuals become eligible, we do not need to consider the corresponding hazard and survival functions separately.

${ }^{24}$ The first dummy is excluded from the equation to avoid colinearity with the constant term.
} 
The likelihood of equation (4) is then maximized using an EM algorithm (Dempster et al., 1977).

\section{Results}

The impact of RMI receipt on unemployment hazard is estimated using three specification. In the first one (specification A), it enters the model as a simple time varying dummy variable $\mathbb{1}_{\left(t_{r}<t\right)}$. This specification thus assumes that the effect of welfare participation is constant over time and across household structures. In the second (specification B), we relax the assumption of a constant impact of RMI receipt over time, and use a series of dummies reflecting the seniority in the program. Finally, specification $\mathrm{C}$ allows the effect of program participation to vary according to the household structure, but not over time.

For each specification, three versions of the models are estimated. In Model (1), program participation and time to eligibility are assumed exogenous ${ }^{25}$. Model (2) allows the unemployment duration and time to treatment to be correlated through their unobserved heterogeneity components, but considers the time to eligibility to be exogenous. Finally, Model (3) is the full model specified in Equation (3) where all processes are jointly modeled. In this last model, one of the probabilities of the heterogeneity distribution had to be constrained to zero in order to reach convergence. As can be seen in Table 5, this probability was already small (lower than 5\%) in Model (2), so that the constraint we imposed has a small impact on the distribution of unobserved heterogeneity.

Results are displayed in five separate tables. Table 2a shows the estimated coefficients for the unemployment hazard equation, excluding the variables controlling for RMI receipt, which are displayed in Table $2 \mathrm{~b}$. Table 3 shows the results for the program participation equation, and Table 4 for time to eligibility. Finally, Table 5 presents the estimates of the unobserved heterogeneity parameters.

The variables used in the unemployment hazard equation are sex, a dummy for unemployment insurance, dummies for household structure, age and education. Macroeconomic conditions are controlled via the local unemployment rate. Independent variables in the participation equation are sex, UI receipt, the local unemployment rate, age, education and household structure. Although the identification of the model does not rely on exclusion restrictions or additional distributional assumptions (Abbring and van den Berg, 2003), we have included, in addition to the set of covariates already present in the unemployment duration equation, the ratio of the rate of RMI recipients in the district to the local unemployment rate. This variable comes as a proxy for social stigma as defined by Besley and Coate (1992).

$\overline{25}$ The second part of Equation 3 is thus dropped from the likelihood of Model (1). 
Their model links the level of social stigma in the society to the difference in average labour disutility between welfare recipients and the rest of the population. Assuming that labour disutility is uniformly distributed in the population, then a higher rate of welfare recipients implies a lower level of labour disutility among welfare recipients. Our proxy is thus inversely proportional to social stigma.

Our comments will first focus on results from Tables $2 \mathrm{a}, 3$ and $4{ }^{26}$ before turning to the coefficients related to program participation in Table $2 b$ and heterogeneity terms (Table 5). Since the estimated coefficients of the unemployment hazard equation in the full model are similar to those from Models (1) and (2), we will focus on Model (3) in our comments of the impact of socio-economic variables. Moreover, the three specifications of the impact of RMI receipt leave other coefficients mostly unchanged.

Consistent with the empirical literature on unemployment spells, the estimates show that the baseline hazard out of unemployment first increases between 0 and 6 months, then decreases steadily afterwards. The coefficient for sex is statistically significant and indicates that the hazard rate for women is about two thirds of that of men. Household structure does not have a significant impact, but couples seem nevertheless to exit from unemployment into employment quicker than singles. Age does have a statistically significant effect on the hazard rate, which declines as the individuals get older. Education is only significant for those who have a college degree in specification $\mathrm{C}$, but coefficients nonetheless indicate that, as expected, the hazard rate increases with education. The local unemployment rate, introduced as a proxy for macroeconomic conditions has a negative, although not significant, impact on the hasard rate. Consistent with the results obtained in the empirical literature on unemployment spells, receipt of UI benefits significantly decreases the hazard by approximately $30 \%$ (1-exp(-0.30)).

Results for the program participation equation (Table 3) show that the baseline hazard for this process is decreasing until month 6 , then strongly increasing. While sex does not have a significant impact on program participation, the hazard rate into RMI receipt is significantly reduced as individuals get older. Household structure also plays a key role in the decision to participate in the welfare program: single parents will choose to benefit from the RMI much earlier than singles without children; while couples without children will tend to experience a longer unemployment spell before participating in the RMI program. The latter are the only ones that do not significantly differ from single persons without children. As expected, UI receipt lowers the hazard rate to program participation by reducing the amount that eligible individual can claim. A higher local unemployment rate, because it lowers the probabilities of finding a stable source of income, greatly increases the hazard into RMI receipt. Finally, the ratio of the rate of RMI recipients to the lo-

\footnotetext{
${ }^{26}$ Since these tables report parameters that are not our primary concern in this paper, we will not dwell on them.
} 
cal unemployment rate, which is used as a proxy inversely proportional to social stigma, significantly increases the hazard into program participation ${ }^{27}$. This is consistent with Terracol (2002), who finds a significant impact of social stigma on the take-up of welfare programs.

Regarding time to eligibility, results shown in Table 4 indicate that the household structure is the main determinant of the duration process leading to RMI eligibility, with singles having the highest hazard rate, followed by single parents, childless couples and couples with children.

We now turn to the impact of welfare receipt and on the coefficients presented in Table $2 \mathrm{~b}$. Looking at the average impact of RMI receipt as estimated in specification A, estimation of the joint model leads to a lower estimated impact of RMI receipt on unemployment hazard than in Model (1), and estimation of the full model leads to a further decrease in the magnitude of the coefficient. This change in coefficients illustrates the bias arising from an improper modeling of the take-up behaviour. If individuals with lower prospects on the labour market tend to take-up their rights to the RMI benefits faster than others, one will observe a spurious negative impact of RMI on hazard rates when this dynamic selection effect is not taken into account.

The coefficient for RMI receipt in Specification A indicates that program participation cuts the hazard rate into unemployment by about $38 \%$. This rather strong disincentive effect of RMI receipt could be explained by the stationary environment it provides to its beneficiaries: being non degressive and involving no sanction in case of lack of adequate job search or other administrative non compliance, the RMI seems to provides few incentives to job seekers. However, as richer specifications will show, this average effect hides large variations in time and the longer term effects of RMI is considerably smaller.

Specification A assumed that the impact of welfare receipt was constant over the whole program participation spell. We now turn to the study of the evolution of the effect of program participation with time.

Unlike unemployment benefit, the RMI provides a stable income to its recipients, for an unlimited duration. Hence, one could expect the effect of RMI receipt to be constant over time. Other factors can nevertheless have an influence on the impact of RMI receipt. A stigma caused by a transition from unemployment insurance to the less valued social status of welfare recipient may lead to a strong effect of RMI receipt in the first months. Conversely, a discouragement leading to a slow withdrawal from the labour market can induce an increase in the effect of RMI receipt over time. In both cases, distinguishing between short and long term effects can be informative on the presence of transitory effects.

\footnotetext{
${ }^{27}$ In model (2), the coefficient of the ratio varies greatly across specifications, but is very robust in Model (3).
} 
We thus introduce a series of dummy variables for the length of ongoing welfare spells : $\mathrm{d}_{r t}, t=1 . .5: \mathrm{d}_{r 1}=\mathbb{1}_{\left(0 \leq t-t_{r} \leq 1\right)} ; \mathrm{d}_{r 2}=\mathbb{1}_{\left(1<t-t_{r} \leq 3\right)} ; \mathrm{d}_{r 3}=\mathbb{1}_{\left(3<t-t_{r} \leq 6\right)} ; \mathrm{d}_{r 4}=$ $\mathbb{1}_{\left(6<t-t_{r} \leq 12\right)}$ and $\mathrm{d}_{r 5}=\mathbb{1}_{\left(t-t_{r}>12\right)}$.

Allowing for time-varying effects of welfare participation leaves other coefficients mostly unchanged. Estimated coefficients show that the impact of RMI receipt on the hazard rate out of unemployment, while strongly negative during the first month, steadily decreases during the first six months of program participation, before stabilizing after month 6 at a low and insignificant level ${ }^{28}$.

In addition to a potential stigma effect, the very strong negative impact of program participation during the first few months can be explained by a sudden increase in the households' income up to a level greater than the last three months' average income. This effect is likely to be strengthened by the fact that recipients actually receive the benefit with a delay of several weeks after signing-up, during which their income is likely to fall further below the guaranteed income.

For some individuals, RMI receipt occurs after the exhaustion of their UI entitlement, and acts as a substitute of the latter. Our estimates suggest that, despite the lower amount brought by the RMI, its effect is, at first, stronger than the average effect of UI benefits, at least during the first six months of program participation. This initial drop if exit rates could be explained by the fact that, contrary to UI rules, RMI recipients face no threat of being excluded from the program for inadequate search activity, and that they are guaranteed to experience no decrease in their benefits. However, a more precise analysis of the effects of switching from UI to RMI would require an explicit modeling of the unemployment benefit entitlement which is beyond the scope of this paper.

The long-term effect (i.e. after 12 months of receipt) of RMI receipt is equivalent to a $14 \%$ decrease in the transition rate into employment. Moreover, this long terme effect is not significantly different from zero. The rather strong average effect of RMI receipt found in Specification A thus hides substantial variations with time and should only be considered as representative of the first year of program participation.

How do these time-varying treatment effects translate into additional time spent into unemployment for RMI recipients? Because the baseline hazard function, the

\footnotetext{
${ }^{28}$ Note that, as in Specification A, Model (3) generally leads to lower estimates of RMI receipt than Models (1) and (2). In particular, longer term effects are now found to be insignificant. Again, theses lower estimates reflect the fact that individuals who quickly enter eligibility and benefit receipt generally have worse unobserved labor market characteristics. Because Models (1) and (2) did not (or did only partly) allow for a correlated unobserved characteristics, the corresponding coefficients were biased towards a stronger negative effect of RMI receipt. The reader should however keep in mind that our relatively unfortunately leads to less precise estimates.
} 
characteristics of individuals remaining in unemployment, and the impact of welfare receipt vary with time, the effect of RMI on unemployment duration might vary with the timing of entry into welfare within the unemployment spell. Using the estimated coefficients of Specification B, Model (2), we have computed the estimated survival function for a representative individual whose characteristics take the average values in the corresponding sub sample under 4 scenarios: (i) if she never benefits from the RMI program - the baseline scenario; (ii) if she begins her welfare spell on her first month of unemployment; (iii) if she begins her welfare spell on her sixth month of unemployment; and (iv) if she begins her welfare spell on her twelfth month of unemployment. Figure 4 plots those estimated survival functions. Because RMI receipt has no impact on hazard rates before $t_{r}$, the estimated survival functions are identical to the baseline one until $t_{r}$. These survival functions allow us to compute the impact of RMI receipt at time $t_{r}$ on the additional unemployment duration. More precisely, given that the individual has been unemployed until $t_{r}$ without receiving welfare payments, what is the impact of taking-up the benefit at $t_{r}$ on the median additional unemployment duration? Table 6 gives, for various values of $t_{r}(1,3,6,9$ and 12 months) the additional median duration of unemployment spells ${ }^{29}$ for those still unemployed at $t_{r}$ under the baseline scenario of no RMI receipt (line 1), and under alternative scenarios where individuals enter welfare in $t_{r}$ (line 2$)^{30}$. The third line of Table 6 gives the additional median unemployment duration induced by taking up the benefit at $t_{r}$, together with the corresponding increase as a percentage of the baseline additional median duration. Figures in the third line of Table 6 answer the following question: if individuals who have been unemployed until $t_{r}$ without welfare participation were randomly assigned to treatment (RMI receipt) and control (no RMI receipt) groups, how much longer would the median unemployment duration be for the treated compared to the controls? These estimates show that RMI receipt adds between 4 and 8 months to the median remaining unemployment duration (between 48 and $69 \%$ of the remaining duration under the baseline scenario), depending on the timing of entry into welfare. The later individuals enter welfare, the stronger will be its impact on unemployment duration. This nonlinearity is driven by the interaction between the nonlinearities in the baseline hazard and the nonlinearities in the treatment effect of program participation, as well as by the fact that individuals that have remained unemployed until the date when we assign them to the program have less favorable characteristics than those who have left earlier.

While the effect of program participation varies with time, it may also differ across household types. Indeed, the income level guaranteed to RMI recipients varies ac-

\footnotetext{
${ }^{29}$ i.e. the median length of time before half of the corresponding population have made a transition into employment.

${ }^{30}$ These durations were computed using the mean values of the regressors for individuals who have remained unemployed until $t_{r}$ without RMI receipt. These 'typical' individuals thus have different characteristics under each scenario because individuals with the most favorable characteristics tend to stay unemployed for a shorter period of time.
} 
Figure 4. Survival functions according to time before RMI receipt

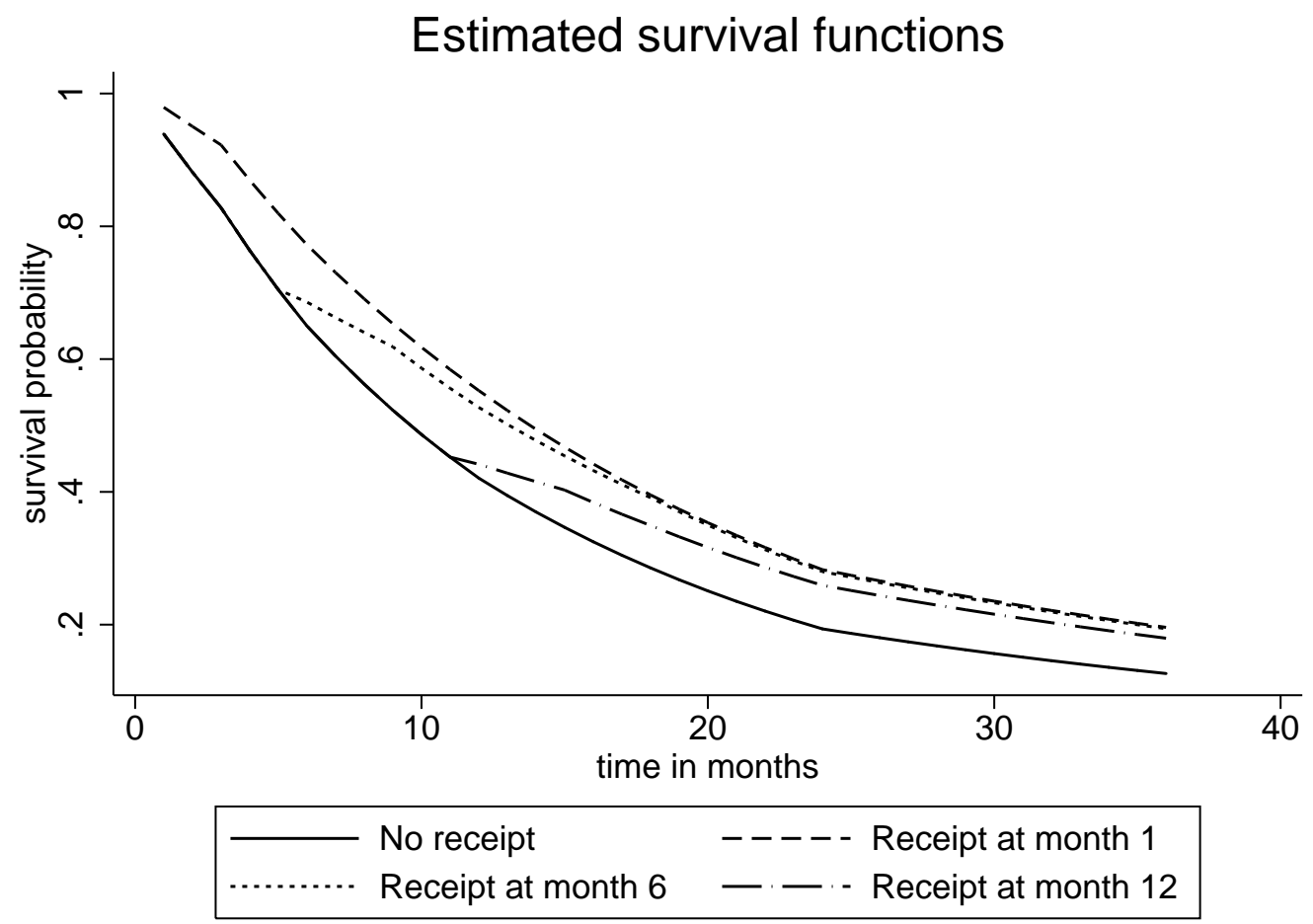

cording to household structure, using an implicit equivalence scale where the second individuals in the household (whether an adult or a child) is given a weight of 0.5 , the third person a weight of 0.3 , and any additional members a weight of 0.4 . Although the second member of a household is given a similar weight regardless of his age, it is unlikely that an unemployed member of a childless couple will behave in the same way as a single mother of one drawing the same amount of benefits from the RMI program. Specification C distinguishes the impact of RMI receipt for four household categories: one-person households, single parents, childless couples and couples with children.

The coefficients for RMI receipt indicate, for all household structures, a weaker effect of program participation on unemployment duration than in the model where program participation is considered exogenous. They remain statistically significant, excepts for single parents, for which no significant effect have been found. The fall in the hazard rate is about $50 \%$ for singles without children, $40 \%$ for couples without children, $33 \%$ for couples with children, and $16 \%$ for single parents.

The estimated impact of program participation is lower for household with children (for couples and singles). The presence of children seems to lower the negative effect of RMI receipt. The increase in the households needs that their presence induce increases their marginal utility of income, and the incentives to increase the 
household's income by exiting from unemployment ${ }^{31}$. The strong effect affecting singles without children may be explained by a discouragement effect affecting this category of unemployed, possibly reinforced by a stronger social insulation.

Results from the three specifications used in our empirical analysis lead to the following conclusion: There is an unambiguous negative effect of RMI on the reemployment rate of its beneficiaries, but this effect is heterogeneous with respect to both household characteristics and seniority in the program. To mitigate these effects, the caseworkers in charge of the "integration" part of the RMI program should focus on the very first months of program participation where the disincentives effect of RMI seem to be the largest ${ }^{32}$. Likewise, single-persons households should be a primary concern for a policy aiming to reduce the negative effect of RMI receipt.

\section{Conclusion}

The problem of potential inactivity traps and labor disincentives generated by welfare benefits such as a guaranteed minimum income is at the heart of the debate on social policy in Europe and the United States. The French Revenu Minimum d'Insertion (RMI) program on which we focus in this article is, with over 1 million households receiving payments, central in the country's welfare system. Initially created as a way to "fill the gaps" in the social safety net, it has increasingly been used as a form of unemployment compensation benefits for individuals who could not qualify for the traditional unemployment insurance system, and is a good candidate for the study of the impact of social welfare receipt on labor supply behavior. In this article, we analyse the effect of RMI receipt on the transition rates from unemployment to employment.

Like many social transfers, RMI suffers from imperfect take-up, and not all eligible households actually choose to apply to the program. The self selection of recipients from a population of eligible bars us from simply contrasting the hazard rates of recipients and non recipients. Instead, we estimate a multivariate duration model à la Abbring and van den Berg (2003) to correct for the endogeneity of RMI receipt.

We find that RMI has a substantial negative impact of the hazard out of unemployment, but that this effect is limited to the first 6 months of receipt, and drops to

\footnotetext{
${ }^{31}$ The RMI being a differential allowance, an increase in family-related benefits will not increase the household's total income for RMI recipients.

${ }^{32}$ Although this paper does not evaluate the impact of an enhancement of the "integration" policy for RMI recipients, it seems natural, as a first approximation, to assume that it will be more efficient if applied to the individuals who are affected the most by the disincentive effects.
} 
insignificant levels afterwards. This estimates imply that RMI receipt adds between 4 and 9 months to unemployment spells, depending on the timing of entry into the program. Moreover, we find that the impact of the program varies across household types, and is weaker in households with children.

\section{References}

Abbring, J. H., Berg, G. J., Ours, J. C., 2005. The effect of unemployment insurance sanctions on the transition rate from unemployment to employment. The Economic Journal 115 (505), 602-630.

Abbring, J. H., van den Berg, G. J., 2003. The nonparametric identification of treatment effects in duration models. Econometrica 71 (5), 1491-1517.

Afsa, C., Guillemot, D., 1999. Plus de la moitié des sorties du rmi se font grâce à l'emploi. INSEE Première 632, INSEE.

Ayala, L., Rodríguez, M., 2006. The latin model of welfare: Do 'insertion contracts' reduce long-term dependence? Labour Economics 13 (6), 799-822.

Besley, T., Coate, S., 1992. Understanding welfare stigma: taxpayer resentment and statistical discrimination. Journal of Public Economics 48 (2), 165-183.

Blank, R. M., December 2002. Evaluating welfare reform in the united states. Journal of Economic Literature 40 (4), 1105-1166.

Blank, R. M., Ruggles, P., 1994. Short-term recidivism among public-assistance recipients. American Economic Review 84 (2), 49-53.

Blank, R. M., Ruggles, P., 1996. When do women use aid to families with dependant children and food stamps? the dynamics of eligibility versus participation. Journal of Human Resources 31 (1), 57-89.

Blundell, R., Fry, V., Walker, I., 1988. Modelling the take-up of means-tested benefits: the case of housing benefits in the united kingdom. The Economic Journal 98 (390, supplement), 58-74.

Bollinger, C. R., David, M. H., 2001. Estimation with response error and nonresponse: Food-stamp participation in the sipp. Journal of Business and Economic Statistics 19 (2), 827-835.

Christofides, L. N., Stengos, T., Swidinsky, R., 1997. Welfare participation and labour market behaviour in canada. Canadian Journal of Economics 30 (3), 595621.

Commissariat Général du Plan, 2000. Minima sociaux, revenus d'activité, précarité. La Documentation française, Paris, rapport du groupe présidé par JeanMichel Belorgey.

Currie, J., 2004. The take-up of social benefits. Discussion Paper 1103, IZA.

Dahan, M., Nisan, U., 2006. Low take-up rates: The role of information. Working Paper 1829, CESifo.

Dempster, A. P., Laird, N. M., Rubin, D. B., 1977. Maximum likelihood from incomplete data via the EM algorithm. Journal of the Royal Statistical Society $39(1), 1-38$. 
Duclos, J.-Y., 1995. Modelling the take-up of state support. Journal of Public Economics 58 (3), 391-415.

Duclos, J.-Y., 1997. Estimating and testing a model of welfare participation: the case of supplementary benefits in britain. Economica 64 (253), 81-100.

Gauthier, S., 2008. Assistance et emploi : le comportement des allocataires du RMI face aux politiques publiques d'incitation à l'emploi. Working Paper 2008-1, CREST.

Granier, P., Joutard, X., 2002. L'influence de la perception du rmi sur la sortie vers l'emploi. Économie et Statistiques (357-358), 23-47.

Grogger, J., Karoly, L. A., 2005. Welfare Reform: Effects of a Decade of Change. Harvard University Pres.

Gurgand, M., Margolis, D. N., 2008. Does work pay in france? monetary incentives and the guaranteed minimum income. Journal of Public Economics 92 (7), 16691697.

Hancock, R., Pudney, S., Barker, G., Hernandez, M., Sutherland, H., 2004. The take-up of multiple means-tested benefits by british pensioners: evidence from the family resources survey. Fiscal Studies 25 (3), 279-303.

Heckman, J. J., Singer, B., 1984. A method for minimizing the impact of distributional assumptions in econometric models for duration data. Econometrica 52 (2), 271-320.

Hernanz, V., Malherbet, F., Pellizzari, M., 2004. Take-up of welfare benefits in oecd countries: a review of the evidence. OECD Social, Employment and Migration Working Papers 17, OECD.

Jacobzone, S., 1996. Les liens entre rmi et chômage, une mise en perspective. Économie et Prévision (122).

Join-Lambert, M.-T., 1998. Chômage : mesures d'urgence et minima sociaux. La Documentation française, Paris, rapport au Premier ministre.

Laroque, G., Salanié, B., 1999. Prélèvements et transferts sociaux : une analyse descriptive des incitations financières au travail. Économie et Statistiques (328).

Laroque, G., Salanié, B., 2000. Une décomposition du non-emploi en France. Économie et Statistiques (331).

Laroque, G., Salanié, B., 2002. Labour market institutions and employment in France. Journal of Applied Econometrics 17 (1), 25-48.

Lhommeau, B., 2001. Les allocataires du rmi : moins d'isolés au sens familial et social que dans la statistique administrative. Économie et Statistiques (346-347), 33-46.

Margolis, D., Starzec, C., 2002. Les aides sociales et l'offre de travail : y a-t-il une trappe à inactivité ? Les cahiers de la MSE, série blanche 2002.21, Université Paris 1.

Maurin, E., Torelli, C., 1992. Rmi et comportement sur le marché du travail. Économie et Statistiques (252).

Michalopoulos, C., Robins, P. K., Card, D., January 2005. When financial work incentives pay for themselves: evidence from a randomized social experiment for welfare recipients. Journal of Public Economics 89 (1), 5-29.

Moffit, R., 2001. The temporary assistance for needy families program. In: Moffit, 
R. (Ed.), Means-Tested Programs in the United States. NBER and University of Chicago Press.

Moffitt, R., 1983. An economic model of welfare stigma. American Economic Review 73 (5), 1023-1035.

Observatoire de l'ANPE, 2002. Les demandeurs d'emploi bénéficiaires du rmi : portrait statistique. Les essemtiels, ANPE.

Piketty, T., 1998. L'impact des incitations financières au travail sur les comportements individuels : une estimation pour le cas français. Économie et Prévision (132-133), 1-35.

Pisani-Ferry, J., 2000. Plein emploi. La Documentation française, Paris, rapport du Conseil d'Analyse Économique $\mathrm{n}^{\mathrm{O}} 30$.

Richardson, K., van den Berg, G. J., Sep. 2006. Swedish labor market training and the duration of unemployment. Discussion Papers 2314, IZA.

Riphahn, R. T., 2001. Rational poverty or poor rationality? the take-up of social assistance benefits. Review of Income and Wealth 47 (3), 379-398.

Terracol, A., 2002. Analysing the take-up of means-tested benefits in france. Tech. rep., Université Paris 1.

Terracol, A., 2003. Essais sur le perception des minima sociaux en france. Ph.D. thesis, Université Paris 1.

van den Berg, G. J., 2001. Duration models: Specification, identification and multiple durations. In: Heckman, J. J., Leamer, E. (Eds.), Handbook of Econometrics, vol. 5. Elsevier Science.

van den Berg, G. J., Lindeboom, M., Ridder, G., Oct.-Dec. 1994. Attrition in longitudinal panel data and the empirical analysis of dynamic labour market behaviour. Journal of Applied Econometrics 9 (4), 421-35.

van den Berg, G. J., van der Klaauw, B., van Ours, J., 2004. Punitive sanctions and the transition rate from welfare to work. Journal of Labor Economics 22 (1), 211-241.

Zoyem, J.-P., 2001. Contrat d'insertion et sortie du rmi. Économie et Statistiques (346-347), 75-102. 


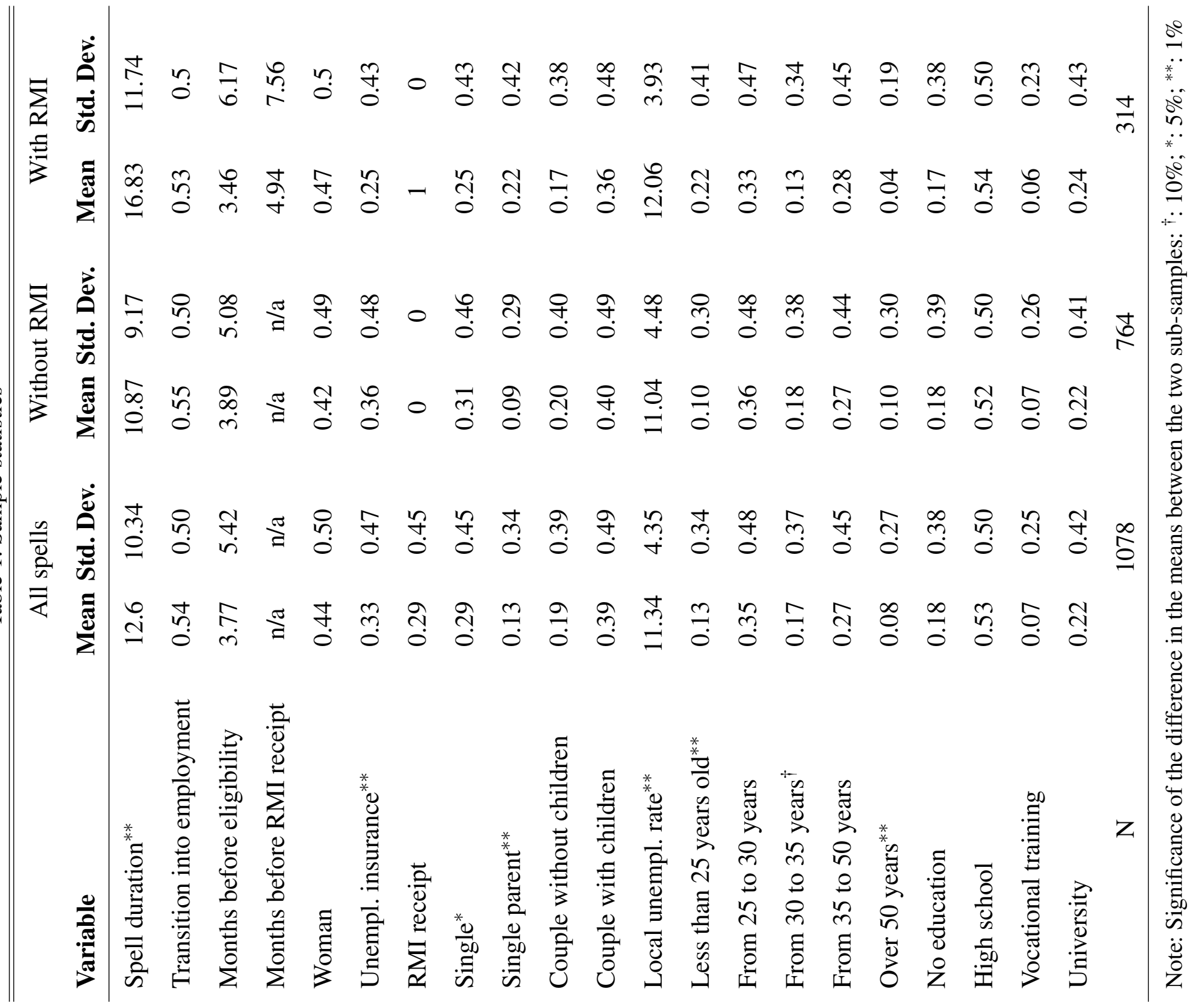




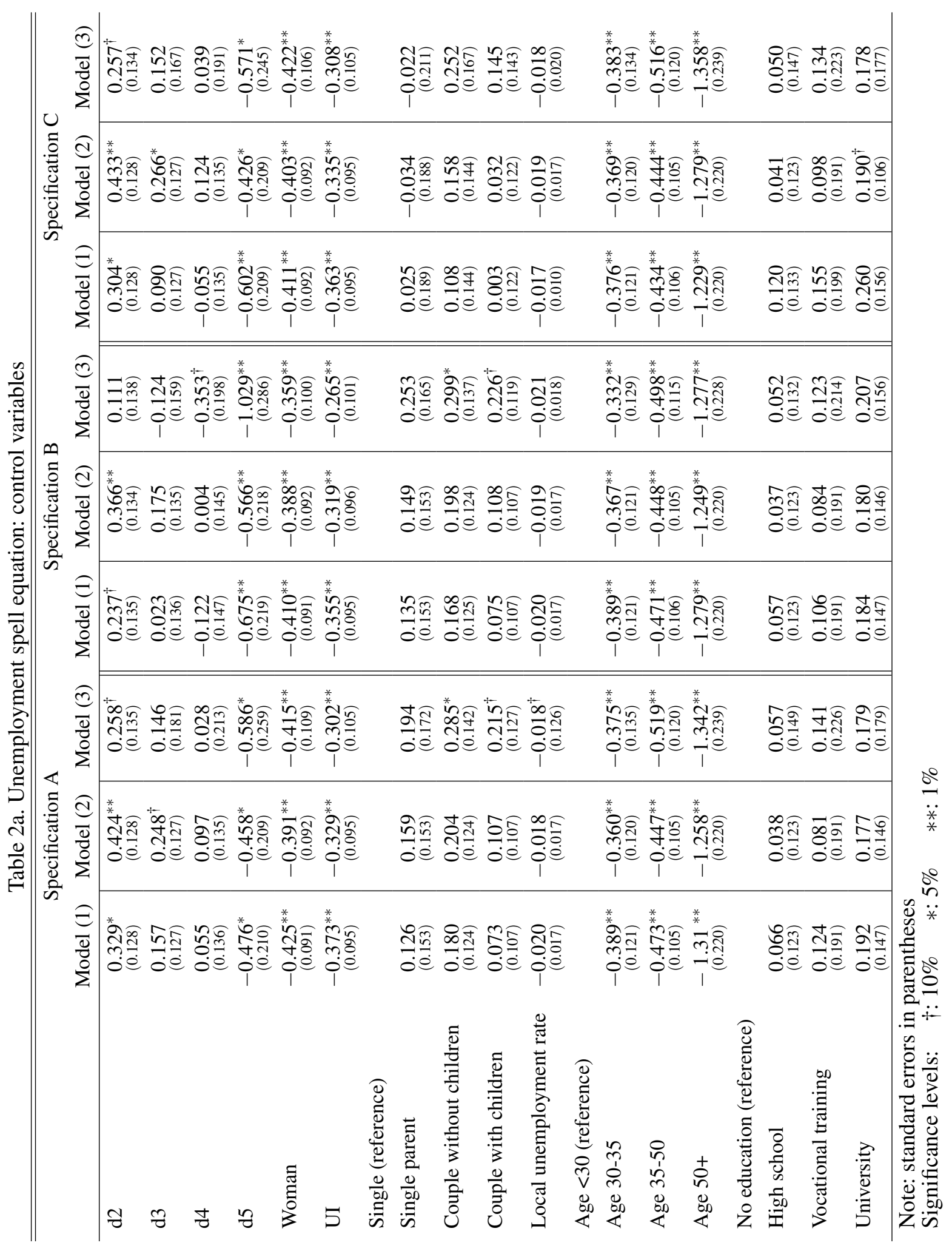




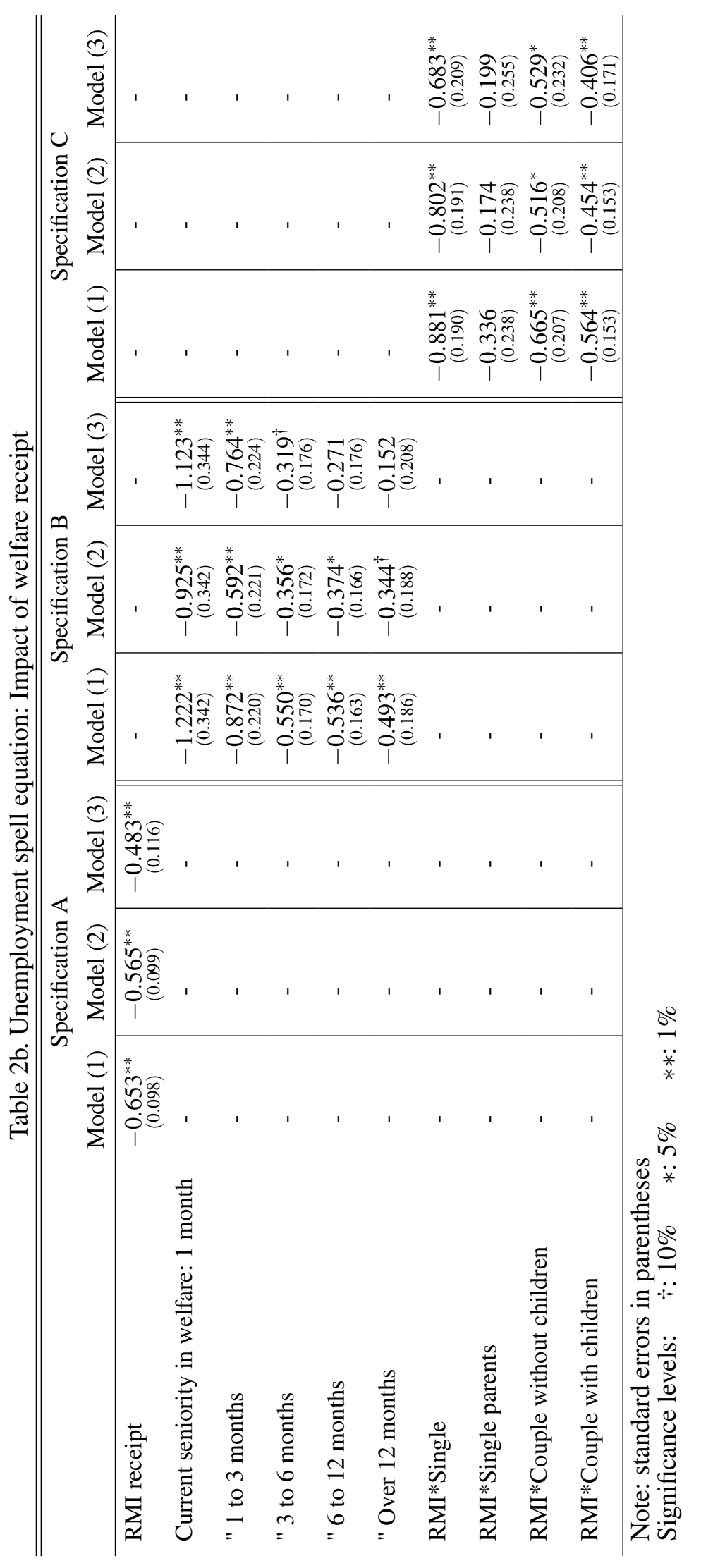


Table 3

Program participation equation

\begin{tabular}{|c|c|c|c|c|c|c|}
\hline & \multicolumn{2}{|c|}{ Specification A } & \multicolumn{2}{|c|}{ Specification B } & \multicolumn{2}{|c|}{ Specification $\mathrm{C}$} \\
\hline & Model (2) & Model (3) & Model (2) & Model (3) & Model (2) & Model (3) \\
\hline $\ln (t)$ & $\begin{array}{l}-3.340^{* *} \\
(0.193)\end{array}$ & $\begin{array}{l}-2.498^{* *} \\
(0.178)\end{array}$ & $\begin{array}{l}-2.202^{* *} \\
(0.237)\end{array}$ & $\begin{array}{l}-2.497^{* *} \\
(0.178)\end{array}$ & $\begin{array}{l}-2.892^{* *} \\
(0.256)\end{array}$ & $\begin{array}{l}-2.496^{* *} \\
(0.178)\end{array}$ \\
\hline $\ln (t)^{2}$ & $\begin{array}{l}0.860^{* *} \\
(0.064)\end{array}$ & $\begin{array}{l}0.470^{* *} \\
(0.059)\end{array}$ & $\begin{array}{l}0.612^{* *} \\
(0.074)\end{array}$ & $\begin{array}{l}0.470^{* *} \\
(0.059)\end{array}$ & $\begin{array}{l}0.755^{* *} \\
(0.079)\end{array}$ & $\begin{array}{l}0.470^{* *} \\
(0.059)\end{array}$ \\
\hline Woman & $\begin{array}{r}-0.068 \\
(0.132)\end{array}$ & $\begin{array}{r}-0.007 \\
(0.119)\end{array}$ & $\begin{array}{r}-0.268 \\
(0.168)\end{array}$ & $\begin{array}{r}-0.005 \\
(0.119)\end{array}$ & $\begin{array}{r}-0.096 \\
(0.169)\end{array}$ & $\begin{array}{r}-0.007 \\
(0.119)\end{array}$ \\
\hline UI & $\begin{array}{c}-0.676^{* *} \\
(0.146)\end{array}$ & $\begin{array}{c}-0.429^{* *} \\
(0.138)\end{array}$ & $\begin{array}{c}-0.403^{*} \\
(0.178)\end{array}$ & $\begin{array}{c}-0.429^{* *} \\
(0.138)\end{array}$ & $\begin{array}{c}-0.542^{* *} \\
(0.176)\end{array}$ & $\begin{array}{c}-0.429^{* *} \\
(0.138)\end{array}$ \\
\hline Local unemployment rate & $\begin{array}{l}0.101^{* *} \\
(0.026)\end{array}$ & $\begin{array}{l}0.056^{*} \\
(0.024)\end{array}$ & $\begin{array}{l}0.084^{*} \\
(0.033)\end{array}$ & $\begin{array}{l}0.056^{*} \\
(0.024)\end{array}$ & $\begin{array}{l}0.063^{* *} \\
(0.032)\end{array}$ & $\begin{array}{l}0.056^{* *} \\
(0.024)\end{array}$ \\
\hline$\frac{\text { rate of RMI recipients in the district }}{\text { local unemployment rate }}$ & $\begin{array}{l}1.780 \\
(1.384)\end{array}$ & $\begin{array}{l}1.545 \\
(1.263)\end{array}$ & $\begin{array}{l}4.530^{*} \\
(1.860)\end{array}$ & $\begin{array}{l}1.541 \\
(1.264)\end{array}$ & $\begin{array}{l}5.809^{* *} \\
(1.832)\end{array}$ & $\begin{array}{l}1.544 \\
(1.263)\end{array}$ \\
\hline Age & $\begin{array}{c}-0.051^{* *} \\
(0.008)\end{array}$ & $\begin{array}{c}-0.028^{* *} \\
(0.006)\end{array}$ & $\begin{array}{l}-0.029^{* *} \\
(0.009)\end{array}$ & $\begin{array}{c}-0.028^{* *} \\
(0.006)\end{array}$ & $\begin{array}{c}-0.031^{* *} \\
(0.008)\end{array}$ & $\begin{array}{c}-0.028^{* *} \\
(0.006)\end{array}$ \\
\hline Education & $-0.094^{\dagger}$ & $\begin{array}{r}-0.055 \\
(0.044)\end{array}$ & $\begin{array}{r}-0.073 \\
(0.061)\end{array}$ & $\begin{array}{r}-0.055 \\
(0.045)\end{array}$ & $\begin{array}{r}-0.016 \\
(0.061)\end{array}$ & $\begin{array}{r}-0.056 \\
(0.044)\end{array}$ \\
\hline \multicolumn{7}{|l|}{ Single (reference) } \\
\hline Single parent & $\begin{array}{l}1.275^{* *} \\
(0.208)\end{array}$ & $\begin{array}{l}0.564^{* *} \\
(0.179)\end{array}$ & $\begin{array}{l}1.313^{* *} \\
(0.266)\end{array}$ & $\begin{array}{l}0.566^{* *} \\
(0.179)\end{array}$ & $\begin{array}{l}1.072^{* *} \\
(0.239)\end{array}$ & $\begin{array}{c}0.5622^{* *} \\
(0.180)\end{array}$ \\
\hline Couple without children & $\begin{array}{r}-0.191 \\
(0.187)\end{array}$ & $\begin{array}{r}-0.101 \\
(0.186)\end{array}$ & $\begin{array}{r}-0.126 \\
(0.253)\end{array}$ & $\begin{array}{r}-0.100 \\
(0.185)\end{array}$ & $\begin{array}{r}-0.216 \\
(0.258)\end{array}$ & $\begin{array}{r}-0.103 \\
(0.186)\end{array}$ \\
\hline Couple with Children & $\begin{array}{r}-0.112 \\
(0.159) \\
\end{array}$ & $\begin{array}{r}-0.106 \\
(0.158) \\
\end{array}$ & $\begin{array}{c}-0.362^{\dagger} \\
(0.211) \\
\end{array}$ & $\begin{array}{r}-0.107 \\
(0.157) \\
\end{array}$ & $\begin{array}{c}-0.479^{*} \\
(0.216) \\
\end{array}$ & $\begin{array}{r}-0.107 \\
(0.158) \\
\end{array}$ \\
\hline
\end{tabular}

Note: standard errors in parentheses

Significance levels: $\quad+: 10 \% \quad *: 5 \% \quad * *: 1 \%$

Table 4

Time to eligibility equation

Specification A Specification B Specification C

\begin{tabular}{lccc} 
Woman & -0.182 & -0.221 & -0.177 \\
& $(0.194)$ & $(0.188)$ & $(0.194)$ \\
Single parent & $-0.472^{\dagger}$ & $-0.506^{\dagger}$ & $-0.473^{\dagger}$ \\
& $(0.290)$ & $(0.279)$ & $(0.290)$ \\
Couple without children & $-0.689^{\dagger}$ & $-0.709^{*}$ & $-0.689^{\dagger}$ \\
& $(0.379)$ & $(0.344)$ & $(0.383)$ \\
Couple with children & $-1.138^{* *}$ & $-1.379^{* *}$ & $-1.389^{* *}$ \\
& $(0.358)$ & $(0.323)$ & $(0.368)$ \\
Age & -0.003 & -0.001 & -0.003 \\
& $(0.010)$ & $(0.009)$ & $(0.009)$ \\
Education & 0.003 & -0.012 & 0.004 \\
& $(0.061)$ & $(0.059)$ & $0.061)$ \\
\hline
\end{tabular}

Note: standard errors in parentheses

Significance levels: $\quad \dagger: 10 \% \quad *: 5 \% \quad * *: 1 \%$ 


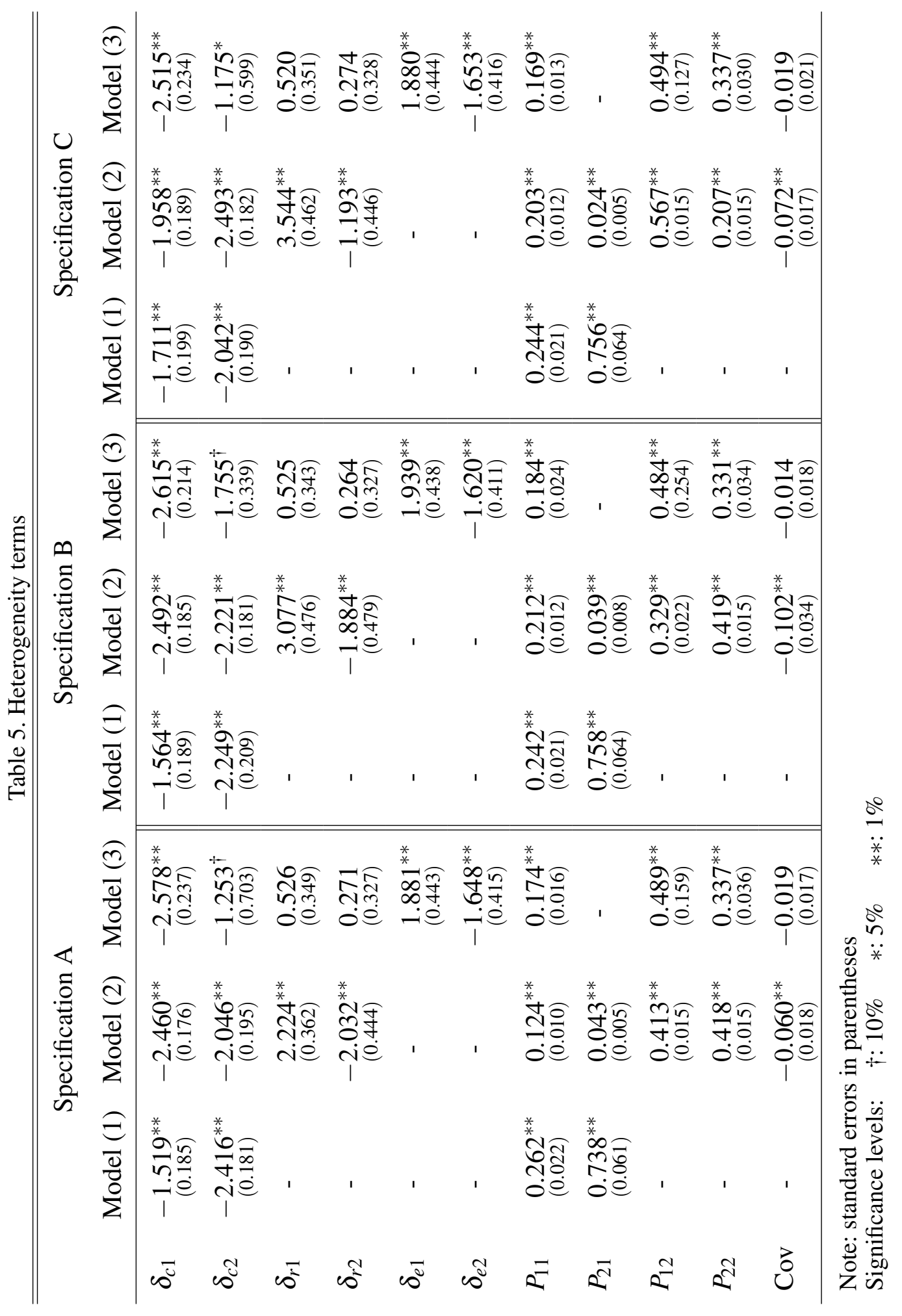


Table 6

Median additional duration at time $t_{r}$

\begin{tabular}{c|ccccc} 
& \multicolumn{7}{c}{$t_{r}$} \\
& 1 & 3 & 6 & 9 & 12 \\
\hline Baseline scenario & 8.63 & 8.73 & 9.48 & 10.82 & 11.09 \\
Receipt at month $t_{r}$ & 12.80 & 13.94 & 14.73 & 16.99 & 19.65 \\
Additional median duration & $\begin{array}{c}4.17 \\
(48.33)\end{array}$ & $\begin{array}{c}5.20 \\
(59.56)\end{array}$ & $\begin{array}{c}5.26 \\
(55.51)\end{array}$ & $\begin{array}{c}6.17 \\
(57.03)\end{array}$ & $\begin{array}{c}8.56 \\
(77.21)\end{array}$ \\
\hline
\end{tabular}

